\title{
Does Interrelationship of Allopregnanolone and Tetrahydrodeoxycorticosterone during Pregnancy and Postpartum Depression Exist? A Review of the Current Evidence
}

\author{
Mansur A Sandhu ${ }^{1 *}$, Muhammad S Anjum ${ }^{1}$, Nasir Mukhtar ${ }^{1}$, Riaz Hussain ${ }^{1}$ and Imtiaz A Khan ${ }^{2}$
}

${ }^{1}$ Department of Veterinary Biomedical Sciences, PMAS-Arid Agriculture University Rawalpindi, 46300, Shamasabad square, Pakistan

${ }^{2}$ Department of Veterinary Pathobiology, PMAS-Arid Agriculture University Rawalpindi, 46300, Shamasabad square, Pakistan

\begin{abstract}
Pregnancy and postpartum changes affect more than a half of women in the world. Neuroactive steroids play a vital role in mental health, behavior, mood development, neuron-protection and memory. This review sums up what is wellknown regarding the two types of neuroactive steroids viz. allopregnanolone (ALP) and tetrahydrodeoxycorticosterone (THDOC). There is a strong correlation between body progesterone concentration and ALP production. The stage of estrus cycles determines the levels of ALP in body, however, THDOC is a stress induced neuroactive steroid and its level is changeable with the type and severity of stress. The physiological response of stress is affected by THDOC and influences paraventricular nucleus in hypothalamus which in turn controls hypothalamic-pituitary-adrenal and gonadal axis. Both neuroactive steroids are potent endogenous modulators of $\gamma$-aminobutyric acid type $A\left(G_{A B A}\right)$ receptors and their production gets higher during pregnancy. Now a question arises "do both classes of neuroactive steroids have a potent correlation in their action?" This manuscript will bring you up to date on the interaction and function of these two during pregnancy and postpartum depression.
\end{abstract}

Keywords: Tetrahydrodeoxycorticosterone; Allopregnanolone; Pregnancy; Postpartum period; Neuroactive steroid; Depression

\section{Introduction}

Neurosteroids like tetrahydrodeoxycorticosterone (THDOC) and allopregnanolone (ALP) are metabolites of steroids and formed by the action of $5 a$-reductase type- 1 and $3 a$-hydroxysteroid dehydrogenase enzymes [1,2]. THDOC and ALP has anticonvulsant, anxiolytic, sedative effects $[3,4]$ and induces behavioural/health changes during pregnancy and menstruation while, anxiety and depression in epilepsy [5-9]. Neuroactive steroids are manufactured in the neurons, astrocytes and glial cells and can be produced from the same tissue [10]. The $\gamma$-aminobutyric acid (GABA) system is one of the many inhibitory systems and present in about $25 \%$ of the brain receptors [11]. There are three types of $\mathrm{GAB}_{\mathrm{A}}$ receptors viz. $\mathrm{GABA}_{\mathrm{A}}, \mathrm{GABA}_{\mathrm{B}}$ and $\mathrm{GABA}_{\mathrm{C}}$. Both of these neuroactive hormones are $G A B A_{A}$ receptor agonist which is pentameric and has an ion channel in its center [12]. Barbiturates are also GABAA agonist, and these anesthetics inhibit ovulation in rats [13]. There is also a known correlation of ALP and THDOC with GnRH, LH and FSH [14]. Since, there are few studies on the function and working of ALP and THDOC, however, the correlation of neurosteroid influencing the pregnancy and postpartum period is not yet well known. It is likely that GABAergic progesterone metabolites work singularly or coordinal to induce physiological/pathologic effects.

\section{What is allopregnanolone?}

ALP is a $3 a$-hydroxy-A ring-reduced steroid. It is synthesized de novo either in brain [15], in the adrenal gland cortex [10,16], and in corpus luteum during the ovulatory menstrual period [17]. The alteration in physiological rhythms of progesterone depends upon stress, stage of menstrual cycle, menopause, and pregnancy. When there is sudden decrease in body progesterone before premenstrual bleeding is the cause of premenstrual syndrome with similar symptoms in the postmenopausal women $[18,19]$. ALP levels gets higher during early and postmenopausal women receiving dehydroepiandrosterone and the values get as much higher as are pragmatic in pregnancy [20]. This steroid metabolite exerts neuromodulatory possessions in CNS and is a $\mathrm{GABA}_{\mathrm{A}}$ receptor agonist that affects mood, modulating anxiety, and memory $[21,22]$. There is a positive correlation between body ALP levels and the level of progesterone [23,24]. In estrus cycle, the body ALP level diverges with the change in phases of estrus. During luteal phase the level of ALP is about four times higher than the follicular phase [25] and gets at its peak with the advancement in pregnancy [24]. Animal studies show that the ALP levels remain elevated in the brain than blood circulation [16]. After the exposure to stress there is an increase of circulating ALP [25] than the normal calm and quite state, however, in adrenalectomized rats [10] the concentration of ALP remained undetectable in the plasma.

\section{What is THDOC?}

An increased activity of hypothalamic-pituitary-adrenal (HPA)axis is due to more production of corticotropin releasing hormone (CRH), which is a key arbitrator of CNS stress [26]. After acute stress the hypothalamus production of $\mathrm{CRH}$ increases that prompts the discharge of ACTH from the anterior pituitary gland, which ultimately excites cortex of the adrenal for the production of glucocorticoids and neuroactive steroid precursors [27]. There are two types of glucocorticoids present eg. cortisol (human \& non-human primates) and corticosterones (rodents); these give negative feedback upon

*Corresponding author: Mansur A Sandhu, Department of Veterinary Biomedical Sciences, Faculty of Veterinary and Animal Sciences, PMAS, Arid Agriculture University, Rawalpindi, Pakistan, Tel: +92-321-7830305; E-mail: mansoorsandhu@uaar.edu.pk

Received November 22, 2013; Accepted December 19, 2013; Published December 26, 2013

Citation: Sandhu MA, Anjum MS, Mukhtar N, Hussain R, Khan IA (2013) Does Interrelationship of Allopregnanolone and Tetrahydrodeoxycorticosterone during Pregnancy and Postpartum Depression Exist? A Review of the Current Evidence. J Steroids Hormon Sci S4: 001. doi:10.4172/2157-7536.S4-001

Copyright: (c) 2013 Sandhu MA, et al. This is an open-access article distributed under the terms of the Creative Commons Attribution License, which permits unrestricted use, distribution, and reproduction in any medium, provided the original author and source are credited. 
Citation: Sandhu MA, Anjum MS, Mukhtar N, Hussain R, Khan IA (2013) Does Interrelationship of Allopregnanolone and Tetrahydrodeoxycorticosterone during Pregnancy and Postpartum Depression Exist? A Review of the Current Evidence. J Steroids Hormon Sci S4: 001. doi:10.4172/21577536.S4-001

Page 2 of 5

the pituitary gland and hypothalamus. To counteract the increase of ACTH or corticosterone in stressed rats $3 \alpha, 5 \alpha$-THDOC come and play its role to decline hypothalamic CRH mRNA levels and vasopressin [28] ultimately ACTH discharge and corticosterone levels of rats. Out of adrenal cortex, the $3 \alpha, 5 a-$ THDOC development calls for the accessibility of deoxycorticosterone, and its synthesis is under ACTH control [29]. This decrease of CRH level may has a positive effect to save animal from stressful conditions, returning the body back towards homeostasis and is critical for mental health in premenstrual dysphoric disorders. However, after adrenalactomy the production of THDOC fades away from the brain along with disappearance of 2l-hydroxylase. THDOC synthesis in brain needs deoxycorticosterone production by adrenal cortex. Interestingly THDOC release is more after stress stimuli. During the time of stress there is about 7-8 folds increase in the formation of THDOC from rat adrenal cortex and in plasma [25,30], it takes about 10-30 minutes to get its peak after stress [4] stimuli. Together with adrenal cortex, THDOC is also renewed from its forerunner in the brain neurons [6]. Enzymatic cleavage of deoxycorticosterone is with $5 a$-reductase and $3 a$-hydroxysteroid oxidoreductase (Figure 1) to form $5 \alpha$-DHDOC and $3 \alpha, 5 \alpha$-THDOC increase during depression.

\section{Interaction of THDOC and ALP with other hormones}

To exert the effects in brain, cortisol also uses mineralocorticoid receptor and its affinity is 10 -folds higher than glucocorticoid receptors. In brain mineralocorticoid receptor is primarily articulated in the hippocampus. Both glucocorticoid and mineralocorticoid receptors are blamed for the production of anxiety and cognitive conditions [31]. Different studies on laboratory animals have confirmed that after stress there is an increase in mineralocorticoid receptor of hippocampus [32,33] and anxiolytic if we block mineralocorticoid receptors [34,35]. On the other hand, Otte et al. [36] demonstrated the inter-relationship of human mineralocorticoid receptor blockage with anxiolytic effects and shown similar results. In human, there is an increased production of plasma cortisol concentration with the use of mineralocorticoid receptor blocking agents as described by Arvat et al. [37] and Wellhoener et al. [38].

The ALP along with THDOC (Figure 2) is potent endogenous modulators of $\mathrm{GABA}_{\mathrm{A}}$ receptors having the role of anxiolytic, anticonvulsant, and sedative actions [39]. Evidences show that THDOC has a predisposition to protect neurons of developing brain in opposition to unfavorable emotional conditions. It is important to note down that, GABAergic agonists have the tendency to persuade behavioral modifications for the period of perinatal life [40]. However the mechanism through which THDOC induces gene transcription of corticoids receptor and neuropeptides remain difficult to understand. Thus the hypothesis was put forward that different neuron-hormones can modulate glucocorticoid receptors and CRH gene transcription [41]. There are strong evidences that neuroactive steroids also interact with steroid receptors, after oxidation THDOC and THP have the tendency to bind with progesterone receptor [42]. With occurrence of catamenial epilepsy seizure there is a sudden decline in progesterone secretion during the premenstrual period [43] and the treatment with progestin is helpful [44]. There may be relationship of seizures attenuation by augmentation of $\mathrm{GAB}_{4}$-mediated inhibition of neural excitability after progestin treatment. Since, progesterone metabolites are potent allosteric modulators of $\mathrm{GABA}_{\mathrm{A}}$ receptors [5]. Recent studies have revealed that serum FSH and $\mathrm{LH}$ reduces after I/V injection of ALP during the follicular phase and a negative relationship was flanked by ALP and FSH. In an animal model the increased concentration of ALP or it's injection to boost the circulating levels has an opposing effects on the circulating levels of GnRH, LH, FSH and this will ultimately suppress the formation of follicle and release of ova $[14,45]$. Similar results of delayed follicular phase with THDOC enhancement are present in rats [13] but no effect in primates [46]. These results can be correlated with human where elevated levels of ALP may induce premature ovarian failure [47].

\section{Relationship of THDOC and ALP with pregnancy and postpartum depression}

Pregnancy is among the most common physiological condition with lofty levels of steroids in a woman at child bearing age that makes her more prone to depression $[48,49]$. This postpartum depression (PPD) is a transitory type during pregnancy and after childbirth. Two forms of PPD: either "baby blues" or "late onset". The baby blues type exists as many as $80 \%$ of women subsequent to delivery and generally resolves in few weeks devoid of treatment. The later onset form of PPD is more ruthless and is diagnosed after few weeks of delivery and its existence is in about $10-16 \%$ of childbearing women. The indications of PPD consist of anxiety, problematic sleep, sadness, memory impairment, mood changes, and tearfulness [50]. An average of $20 \%$ women with blues will expand long-term depression. There are evidences that infant-mother bond gets disturbed with PPD [51] and later problems in child's socio-emotional development [52,53]. In adrenal and CNS, neuroactive steroids (THDOC and ALP) are created de novo from cholesterol (Figure 2) [54] and the change in levels of steroid hormone ultimately changes the levels of neuroactive steroids [54]. A variety of physiological (pregnancy) and pathological (stress) alterations in the body lead to modify the levels of neuroactive steroids in the CNS. Exogenous administration of steroid hormones results in depression merely among all the women those have the history of postpartum depression [55]. This shows that some women must be predisposed to postpartum depression. Every individual either human or animal are at all times under the challenges of stress. Though, all

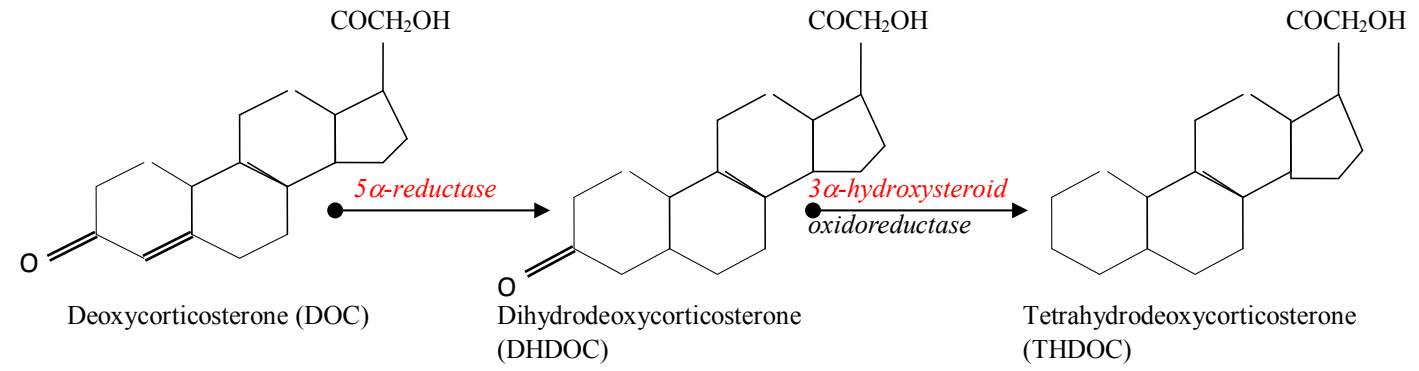

Figure 1: Structural alteration of Deoxycorticosterone (DOC) to $5 \alpha$-dihydrodeoxycorticosterone (DHDOC) and then Tetrahydrodeoxycorticosterone (THDOC) through enzymes $5 \alpha$ reductase and $3 \alpha$ hydroxysteroid oxidoreductase. 
Citation: Sandhu MA, Anjum MS, Mukhtar N, Hussain R, Khan IA (2013) Does Interrelationship of Allopregnanolone and Tetrahydrodeoxycorticosterone during Pregnancy and Postpartum Depression Exist? A Review of the Current Evidence. J Steroids Hormon Sci S4: 001. doi:10.4172/21577536.S4-001

Page 3 of 5

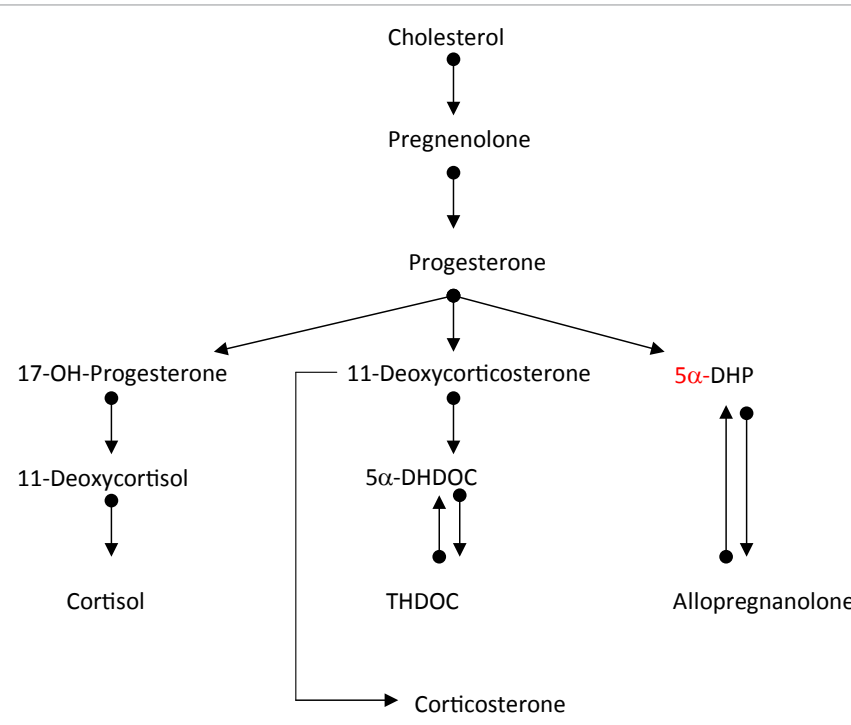

Figure 2: The creation of neurosteroids from cholesterol along with metabolic pathway. DHDOC=Dihydrodeoxycorticosterone, THDOC=Tetrahydrodeoxycort costerone, DHP=Dihydroprogesterone.

Pregnancy, Post Menopause receiving Dehydroepiandrosterone, Luteal phase

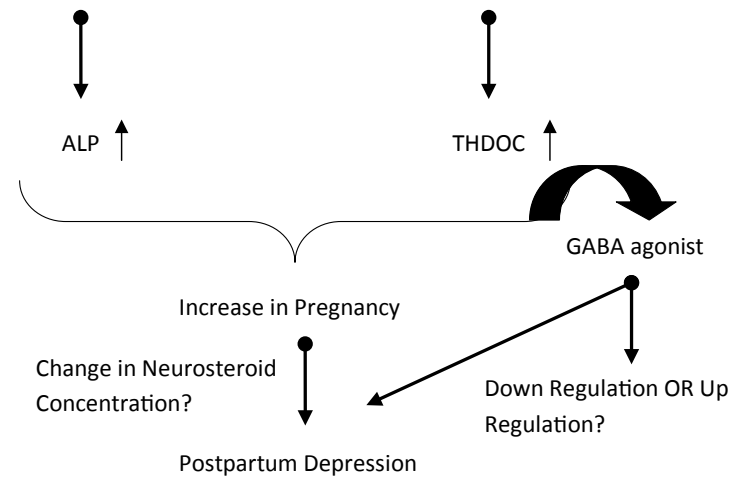

Figure 3: The flow diagram showing events and possible neurosteroids correlations in the creation of pregnancy and postpartum depression. $\mathrm{CRH}=$ corticotrophin releasing hormone; $\mathrm{ACTH}=$ Adrenocorticotropic hormone; THDOC=tetrahydrodeoxycorticosterone; $\mathrm{ALP}=$ allopregnanolone; GABA=aminobutyric acid receptor.

environments pose its unique set of stresses and the body must be talented for proper response to maintain homeostasis [56]. The stress in pregnancy also activates HPA-axis resulting in overproduction of corticosteroids and high levels in both circulating and brain THDOC (from 1-5 $\mathrm{nM}$ to 15-30 $\mathrm{nM}$ ) as given by Reddy and Rogawski, [3]; Maguire and Mody, [57] and ALP (about 8-folds) as described by Purdy et al. [10]. Another factor of increased ALP during pregnancy is high levels of progesterone (about 200-folds) [58] and exogenous steroids especially in the treatment of preterm labour may results in an increases of neuroactive steroids ALP and THDOC [59]. So, we can state that both THDOC and ALP are important in pregnancy and have a direct role in PPD production. Neuroactive steroids such as $3 \alpha, 5 \alpha$-tetrahydroprogesterone (THP) and THDOC work mutually as positive modulators of $\mathrm{GABA}_{\mathrm{A}}$ receptors [60]. With the use of antidepressant medicines the production of THP and THDOC in rat's brain increase with no change in blood levels [61]. In a human study imbalance in these neurostroids was observed with the use of fluoxetine and fluvoxamine and control group got higher levels of neurostroids then clinically depressed patients [62]. During first trimester of gestation noticeable dizziness is pragmatic, which is later decreased in next trimesters of the gestation. This can be correlated with the levels of neuroactive steroids, even in later pregnancy progesterone and ALP gets higher those effects on sedation. In non-pregnant women sedation takes place with lower concentrations of ALP [63]. This may be due to $\mathrm{GABA}_{\mathrm{A}}$ tolerance to ALP at some stage in pregnancy. Perhaps, the change in mood and neurological disorders during PPD is due to down regulation of $\mathrm{GABA}_{\mathrm{A}}$ receptors during pregnancy, as there is abrupt fall of progesterone and their metabolites. The results of an animal study reveals that, at 18 days of rat pregnancy a decline in the appearance of GABA receptor $\delta$ subunit in hippocampus was observed, which bounces back to virgin levels within 48 hours postpartum [64]. The eminently high levels of THDOC not only affect GABA but also alter neuronal excitability. The psychological health changes of the 'third day blues' and PPD $[65,66]$ are hormone-related indications similarly as premenstrual dysphoric disorder [67]. It is also stated that $\mathrm{GABA}_{A}$ receptors down-regulated is one among all causes of adverse behavior change. However, Sanna et al. [68] stated more complex regulation of GABA receptors throughout pregnancy or there may be species differences in steroid hormone-mediated $\mathrm{GABA}_{\mathrm{A}}$ receptors regulation. They proposed if there is deficiency of $\mathrm{GABA}_{\mathrm{A}}$ receptor regulation in pregnancy and postpartum period, this may influence mood disarray during postpartum such as PPD. The association of mood disorders with postpartum period is particularly related to changing levels of steroid hormone or the site of steroid hormone action namely the GABA receptor $\delta$ subunit. When the mice are deficient in $\mathrm{GABA}_{\mathrm{A}}$ receptor $\delta$ subunit ( $\mathrm{Gabrd}^{-1-}$ mice), they show signs of depression within 48 hours postpartum with forced swimming stress. These mice also fail to make nest and keep their pups away from dam those die due to neglecting behavior or cannibalism $[63,64]$. Based on the presented data we can put forward a hypothesis (Figure 3 ) that different psychological changes, mood disorders, intolerance, and problematic sleep may be due to the change in neurosteroid (ALP and THDOC) concentration, sensitivity or down/up regulation of the hormone/GABA $\mathrm{A}_{\mathrm{A}}$ receptors.

\section{Concluding Remarks}

The authors have tried to summarize the evidences pertaining THDOC and ALP with pregnancy and postpartum depression (PPD). Though discussion is very brief, still we can state that a strong correlation exists between THDOC and ALP. Both of these neuroactive steroids have anxiolytic, anticonvulsant and other protective properties. Almost all neuroactive steroids share similar receptors for steroid hormones, have an important role in the up-regulation and down-regulations of $\mathrm{GABA}_{\mathrm{A}}$ receptors. Further studies are strongly needed before ascertaining any conclusion from the interactions of neuroactive steroids with other endocrine hormones, responses in stress, pregnancy and generation of postpartum depression.

\section{References}

1. Hosie AM, Wilkins ME, da Silva HM, Smart TG (2006) Endogenous neurosteroids regulate GABAA receptors through two discrete transmembrane sites. Nature 444: 486-489.

2. Agís-Balboa RC, Pinna G, Zhubi A, Maloku E, Veldic M, et al. (2006) Characterization of brain neurons that express enzymes mediating neurosteroid biosynthesis. Proc Natl Acad Sci U S A 103: 14602-14607.

3. Reddy DS, Rogawski MA (2002) Stress-induced deoxycorticosterone-derived neurosteroids modulate $\mathrm{GABA}(\mathrm{A})$ receptor function and seizure susceptibility. J Neurosci 22: 3795-3805. 
Citation: Sandhu MA, Anjum MS, Mukhtar N, Hussain R, Khan IA (2013) Does Interrelationship of Allopregnanolone and Tetrahydrodeoxycorticosterone during Pregnancy and Postpartum Depression Exist? A Review of the Current Evidence. J Steroids Hormon Sci S4: 001. doi:10.4172/21577536.S4-001

Page 4 of 5

4. Reddy DS (2003) Pharmacology of endogenous neuroactive steroids. Crit Rev Neurobiol 15: 197-234

5. Tuveri A, Paoletti AM, Orrù M, Melis GB, Marotto MF, et al. (2008) Reduced serum level of THDOC, an anticonvulsant steroid, in women with perimenstrual catamenial epilepsy. Epilepsia 49: 1221-1229.

6. Reddy DS (2003) Is there a physiological role for the neurosteroid THDOC in stress-sensitive conditions? Trends Pharmacol Sci 24: 103-106.

7. Reddy DS (2006) Physiological role of adrenal deoxycorticosterone-derived neuroactive steroids in stress-sensitive conditions. Neuroscience 138: 911 920.

8. Eser D, Schüle C, Baghai TC, Romeo E, Rupprecht R (2006) Neuroactive steroids in depression and anxiety disorders: clinical studies. Neuroendocrinology 84: 244-254.

9. Maguire J, Mody I (2007) Neurosteroid synthesis-mediated regulation of GABA(A) receptors: relevance to the ovarian cycle and stress. J Neurosci 27 : 2155-2162.

10. Purdy RH, Morrow AL, Moore PH Jr, Paul SM (1991) Stress-induced elevations of gamma-aminobutyric acid type A receptor-active steroids in the rat brain. Proc Natl Acad Sci U S A 88: 4553-4557.

11. Hendry SH, Schwark HD, Jones EG, Yan J (1987) Numbers and proportions of GABA-immunoreactive neurons in different areas of monkey cerebral cortex. J Neurosci 7: 1503-1519.

12. Nayeem N, Green TP, Martin IL, Barnard EA (1994) Quaternary structure of the native GABAA receptor determined by electron microscopic image analysis. J Neurochem 62: 815-818.

13. Hagino N, Ramaley JA, Gorski RA (1966) Inhibition of estrogen-induced precocious ovulation by pentobarbital in the rat. Endocrinology 79: 451-454.

14. Timby $E$, Hedström $H$, Bäckström $T$, Sundström-Poromaa I, Nyberg $S$, et al. (2011) Allopregnanolone, a GABAA receptor agonist, decreases gonadotropin levels in women. A preliminary study. Gynecol Endocrinol 27: 1087-1093.

15. Melcangi RC, Magnaghi V, Martini L (1999) Steroid metabolism and effects in central and peripheral glial cells. J Neurobiol 40: 471-483.

16. Corpéchot C, Young J, Calvel M, Wehrey C, Veltz JN, et al. (1993) Neurosteroids: 3 alpha-hydroxy-5 alpha-pregnan-20-one and its precursors in the brain, plasma, and steroidogenic glands of male and female rats. Endocrinology 133: 1003-1009

17. Ottander U, Poromaa IS, Bjurulf E, Skytt A, Bäckström T, et al. (2005) Allopregnanolone and pregnanolone are produced by the human corpus luteum. Mol Cell Endocrinol 239: 37-44

18. Bicíková M, Dibbelt L, Hill M, Hampl R, Stárka L (1998) Allopregnanolone in women with premenstrual syndrome. Horm Metab Res 30: 227-230.

19. Genazzani AR, Petraglia F, Bernardi F, Casarosa E, Salvestroni C, et al (1998) Circulating levels of allopregnanolone in humans: gender, age, and endocrine influences. J Clin Endocrinol Metab 83: 2099-2103.

20. Luisi S, Petraglia F, Benedetto C, Nappi RE, Bernardi F, et al. (2000) Serum allopregnanolone levels in pregnant women: changes during pregnancy, at delivery, and in hypertensive patients. J Clin Endocrinol Metab 85: 2429-2433.

21. Robel P, Baulieu EE (1994) Neurosteroids Biosynthesis and function. Trends Endocrinol Metab 5: 1-8

22. Baulieu EE, Robel P, Schumacher M (2001) Neurosteroids: beginning of the story. Int Rev Neurobiol 46: 1-32.

23. Wang M, Seippel L, Purdy RH, Bãckström T (1996) Relationship between symptom severity and steroid variation in women with premenstrual syndrome: study on serum pregnenolone, pregnenolone sulfate, 5 alpha-pregnane-3,20dione and 3 alpha-hydroxy-5 alpha-pregnan-20-one. J Clin Endocrinol Metab 81: 1076-1082.

24. Parízek A, Hill M, Kancheva R, Havlíková H, Kancheva L, et al. (2005) Neuroactive pregnanolone isomers during pregnancy. $\mathrm{J}$ Clin Endocrinol Metab 90: 395-403.

25. Havlíková H, Hill M, Kancheva L, Vrbíková J, Pouzar V, et al. (2006) Serum profiles of free and conjugated neuroactive pregnanolone isomers in nonpregnant women of fertile age. J Clin Endocrinol Metab 91: 3092-3099.

26. Serra M, Pisu MG, Littera M, Papi G, Sanna E, et al. (2000) Social isolation- induced decreases in both the abundance of neuroactive steroids and GABA(A) receptor function in rat brain. $J$ Neurochem 75: 732-740.

27. Holsboer F, Spengler D, Heuser I (1992) The role of corticotropin-releasing hormone in the pathogenesis of Cushing's disease, anorexia nervosa, alcoholism, affective disorders and dementia. Prog Brain Res 93: 385-417.

28. Patchev VK, Montkowski A, Rouskova D, Koranyi L, Holsboer F, et al. (1997) Neonatal treatment of rats with the neuroactive steroid tetrahydrodeoxycorticosterone (THDOC) abolishes the behavioral and neuroendocrine consequences of adverse early life events. J Clin Invest 99: 962-966.

29. Mensah-Nyagan AG, Do-Rego JL, Beaujean D, Luu-The V, Pelletier G, et al (1999) Neurosteroids: expression of steroidogenic enzymes and regulation of steroid biosynthesis in the central nervous system. Pharmacol Rev 51: 63-81.

30. Barbaccia ML, Concas A, Serra M, Biggio G (1998) Stress and neurosteroids in adult and aged rats. Exp Gerontol 33: 697-712.

31. de Kloet ER, Joëls M, Holsboer F (2005) Stress and the brain: from adaptation to disease. Nat Rev Neurosci 6: 463-475.

32. Ladd CO, Huot RL, Thrivikraman KV, Nemeroff CB, Plotsky PM (2004) Long term adaptations in glucocorticoid receptor and mineralocorticoid receptor mRNA and negative feedback on the hypothalamo-pituitary-adrenal axis following neonatal maternal separation. Biol Psychiatry 55: 367-375.

33. Sandi C, Touyarot K (2006) Mid-life stress and cognitive deficits during early aging in rats: individual differences and hippocampal correlates. Neurobio Aging 27: 128-140.

34. Smythe JW, Murphy D, Timothy C, Costall B (1997) Hippocampa mineralocorticoid, but not glucocorticoid, receptors modulate anxiety-like behavior in rats. Pharmacol Biochem Behav 56: 507-513.

35. Bitran D, Shiekh M, Dowd JA, Dugan MM, Renda P (1998) Corticosterone is permissive to the anxiolytic effect that results from the blockade of hippocampal mineralocorticoid receptors. Pharmacol Biochem Behav 60: 879-887.

36. Otte C, Moritz S, Yassouridis A, Koop M, Madrischewski AM, et al. (2007) Blockade of the mineralocorticoid receptor in healthy men: effects on experimentally induced panic symptoms, stress hormones, and cognition Neuropsychopharmacology 32: 232-238.

37. Arvat E, Maccagno B, Giordano R, Pellegrino M, Broglio F, et al. (2001) Mineralocorticoid receptor blockade by canrenoate increases both spontaneous and stimulated adrenal function in humans. J Clin Endocrino Metab 86: 3176-3181.

38. Wellhoener P, Born J, Fehm HL, Dodt C (2004) Elevated resting and exercise-induced cortisol levels after mineralocorticoid receptor blockade with canrenoate in healthy humans. J Clin Endocrinol Metab 89: 5048-5052.

39. Reddy DS, Kulkarni SK (2000) Development of neurosteroid-based nove psychotropic drugs. Prog Med Chem 37: 135-175.

40. Schroeder H, Humbert AC, Koziel V, Desor D, Nehlig A (1995) Behavioral and metabolic consequences of neonatal exposure to diazepam in rat pups. Exp Neurol 131: 53-63.

41. Rage F, Jalaguier S, Rougeot C, Tapia-Arancibia L (1993) GABA inhibition of somatostatin gene expression in cultured hypothalamic neurones. Neuroreport 4: $320-322$

42. Rupprecht R, Reul JM, Trapp T, van Steensel B, Wetzel C, et al. (1993) Progesterone receptor-mediated effects of neuroactive steroids. Neuron 11: 523-530.

43. Herzog AG, Klein P, Ransil BJ (1997) Three patterns of catamenial epilepsy Epilepsia 38: 1082-1088.

44. Herzog AG (1995) Progesterone therapy in women with complex partial and secondary generalized seizures. Neurology 45: 1660-1662.

45. Sullivan SD, Moenter SM (2003) Neurosteroids alter gamma-aminobutyric acid postsynaptic currents in gonadotropin-releasing hormone neurons: a possible mechanism for direct steroidal control. Endocrinology 144: 4366-4375.

46. Hagino N (1979) Effect of nembutal on LH release in baboons. Horm Metab Res 11: 296-300.

47. Bernardi F, Hartmann B, Casarosa E, Luisi S, Stomati M, et al. (1998) High levels of serum allopregnanolone in women with premature ovarian failure. Gynecol Endocrinol 12: 339-345. 
Citation: Sandhu MA, Anjum MS, Mukhtar N, Hussain R, Khan IA (2013) Does Interrelationship of Allopregnanolone and Tetrahydrodeoxycorticosterone during Pregnancy and Postpartum Depression Exist? A Review of the Current Evidence. J Steroids Hormon Sci S4: 001. doi:10.4172/21577536.S4-001

Page 5 of 5

48. Myers JK, Weissman MM, Tischler GL, Holzer CE 3rd, Leaf PJ, et al. (1984) Six-month prevalence of psychiatric disorders in three communities 1980 to 1982. Arch Gen Psychiatry 41: 959-967.

49. O'Hara MW, Swain AM (1996) Rates and risk of postpartum depression: a meta-analysis. Int Rev Psychiatry 8: 37-54

50. Zonana J, Gorman JM (2005) The neurobiology of postpartum depression. CNS Spectr 10: 792-799, 805.

51. Cummings ME, Davies PT (1992) prenatal depression, family functioning, and child adjustment: risk factors, processes, and pathways. In: Cicchetti D, Toth SL, eds. Development Perspectives on Depression. Rochester, NY: University of Rochester Press. 283-322.

52. Downey G, Coyne JC (1990) Children of depressed parents: an integrative review. Psychol Bull 108: 50-76.

53. Patel M, Bailey RK, Jabeen S, Ali S, Barker NC, et al. (2012) Postpartum depression: a review. J Health Care Poor Underserved 23: 534-542.

54. Stoffel-Wagner B (2001) Neurosteroid metabolism in the human brain. Eur $J$ Endocrinol 145: 669-679.

55. Bloch M, Schmidt PJ, Danaceau M, Murphy J, Nieman L, et al. (2000) Effects of gonadal steroids in women with a history of postpartum depression. Am J Psychiatry 157: 924-930.

56. Sandhu MA, Mirza FQ, Afzal F, Mukhtar N (2012) Effect of heat stress on cellular and humoral immunity and its cure with a-tocopherol in meat type birds. Livestock Sci 148: 181-188.

57. Maguire J, Mody I (2009) Steroid hormone fluctuations and $\operatorname{GABA}(A) R$ plasticity. Psychoneuroendocrinology 34 Suppl 1: S84-90.

58. Bäckström T, Andersson A, Andreé L, Birzniece V, Bixo M, et al. (2003) Pathogenesis in menstrual cycle-linked CNS disorders. Ann N Y Acad Sci 1007: 42-53.
59. Concas A, Mostallino MC Porcu P, Follesa P, Barbaccia ML et al. (1998) Role of brain allopregnanolone in the plasticity of gamma-aminobutyric acid type A receptor in rat brain during pregnancy and after delivery. Proc Nat Acad Sci U S A 95: 13284-13289.

60. Lambert JJ, Belelli D, Hill-Venning C, Peters JA (1995) Neurosteroids and GABAA receptor function. Trends Pharmacol Sci 16: 295-303.

61. Uzunov DP, Cooper TB, Costa E, Guidotti A (1996) Fluoxetine-elicited changes in brain neurosteroid content measured by negative ion mass fragmentography. Proc Natl Acad Sci U S A 93: 12599-12604.

62. Uzunova V, Sheline Y, Davis JM, Rasmusson A, Uzunov DP, et al. (1998) Increase in the cerebrospinal fluid content of neurosteroids in patients with unipolar major depression who are receiving fluoxetine or fluvoxamine. P Nat Acad Sci USA 95: 3239-3244.

63. Timby E, Balgård M, Nyberg S, Spigset O, Andersson A, et al. (2006) Pharmacokinetic and behavioral effects of allopregnanolone in healthy women. Psychopharmacology (Berl) 186: 414-424.

64. Maguire J, Mody I (2008) GABA(A)R plasticity during pregnancy: relevance to postpartum depression. Neuron 59: 207-213.

65. Nemeroff CB (2008) Understanding the pathophysiology of postpartum depression: implications for the development of novel treatments. Neuron 59 : $185-186$

66. Pearlstein T, Howard M, Salisbury A, Zlotnick C (2009) Postpartum depression Am J Obstet Gynecol 200: 357-364.

67. Bloch M, Rotenberg N, Koren D, Klein E (2006) Risk factors for early postpartum depressive symptoms. Gen Hosp Psychiatry 28: 3-8.

68. Sanna E, Mostallino MC, Murru L, Carta M, Talani G, et al. (2009) Changes in expression and function of extrasynaptic GABAA receptors in the rat hippocampus during pregnancy and after delivery. J Neurosci 29: 1755-1765.
This article was originally published in a special issue, Neurosteroids handled by Editor. Dr. Salman Azhar, Stanford University, USA 